\title{
Kaitan Antara Kondisi Keamanan Lingkungan terhadap Jumlah Industri Mikro dan Kecil pada Perdesaan di Indonesia
}

\author{
Muhammad Dwi Prasetiyo $^{1}$, Ni Made Sukartini ${ }^{2}$ \\ ${ }^{1}$ Magister Ilmu Ekonomi, Fakultas Ekonomi dan Bisnis, Universitas Airlangga \\ Surabaya/Badan Pusat Statistik Kabupaten Minahasa Selatan Provinsi Sulawesi Utara; \\ ${ }^{2}$ Fakultas Ekonomi dan Bisnis Universitas Airlangga Surabaya \\ Email corresponding author: md.prasetiyo@bps.go.id
}

\begin{abstract}
ABSTRAK
Sektor usaha di Indonesia pada saat ini masih didominasi oleh usaha atau industrimikro kecil. Pada Tahun 2016 jumlah usaha ini mencapai lebih dari 26 juta usaha atau setara dengan 98,68 persen dari total usaha non pertanian di Indonesia. Penelitian ini bertujuan untuk mengetahui apakah kondisi keamanan lingkungan menghambat proses industrialisasi pada wilayah perdesaan di Indonesia pada Tahun 2018. Data yang digunakan adalah data sekunder yang bersumber dari hasil pendataan potensi desa (Podes) Tahun 2018 oleh BPS RI. Metode yang digunakan dalam penelitian ini menggunakan regresi dummy variabel dengan menggunakan metode estimasi ordinary least square (OLS).Hasil yang diperoleh dari penelitian ini adalah tindak kejahatan seperti pencurian dan penipuan signifikan mempengaruhi sebagian besar industri mikro dan kecil yang ada di perdesaan. Namun hal yang menarik dari penelitian ini adalah ketika ada kejadian tindak kejahatan pencurian dan penipuan membuat jumlah industri mikro dan kecil menjadi lebih tinggi dibandingkan saat tidak ada aktivitas kedua tindak kejahatan tersebut. Hal ini menunjukkan rata-rata keberadaan industri mikro dan kecil di perdesaan Indonesia belum mempertimbangkan lokasi yang memiliki kecenderungan daerah dengan kerawanan sosial yang rendah seperti ditandai dengan minimnya atau rendahnya aktivitas tindak kejahatan di lokasi tersebut.
\end{abstract}

Kata Kunci: Industri Mikro dan Kecil, Podes, Tindak Kejahatan, OLS

\section{PENDAHULUAN}

Industri mikro dan kecil (IMK) atau usaha mikro dan kecil (UMK) merupakan aktivitas ekonomi dan bagian dari sektor industri yang masih dominan di Indonesia saat ini. IMK memegang peranan penting dalam menggerakkan roda perekonomian lokal bagi hampir sebagian besar penduduk Indonesia (BPS, 2019; Sato, 2000).Data Kementerian Koperasi dan UMKM serta Badan Pusat Statistik (BPS) menunjukkan bahwa jumlah atau unit IMK dilaporkan mencapai 99,9 persen dari total usaha non pertanian di Indonesia pada Tahun 2017. Persentase ini mengalami kenaikan sebesar 1,22 persen dibandingkan tahun sebelumnya.IMKdapat berkontribusi terhadap Produk Domestik Bruto (PDB) sebesar 42,9 persen.Unit usaha IMK mencapai lebih dari 62 juta unit industri. Di sisi yang lain, industri atau usaha menengah dan besar menyumbang PDB nasional pada Tahun 2017 sebesar 57,10 persen dengan jumlah unit usaha hanya sebesar 0,1 persen dari total usaha nasional. Salah satu keunggulan dari IMK adalah dalam hal penyerapan jumlah tenaga kerja. Pada Tahun 2017 saja IMK mampu menyerap 93,18 persen dari total tenaga kerja nasional, dimana 87,74 persen diserap oleh industri berskala mikro. Namun dengan jumlah unit yang cukup banyak ini, IMK masih berkontribusi rendah dalam hal ekspor barang non migas. IMK dapat memberikan kontribusi hingga 3,65 persen dari total ekspor non migas sedangkan selebihnya masih didiminasi oleh industri menengah dan besar (IMB) atau usaha menengah dan besar (UMB). Kontribusi Usaha Mikro Kecil dan Menengah (UMKM) terhadap perekonomian nasional padaTahun 2017 dapat dilihat pada Gambar 1 berikut.

Industri kecil dan menengah dapat mendukung pengembangan ekonomi di suatu negara. Salah satu peran penting dari indutri tersebut adalah dalam hal pengentasan kemiskinan melalui penciptaan lapangan kerja (Akhtar, 1997;Mazzarol dkk, 1999). Penelitian yang dilakukan oleh EIM BusinessdanPolicy Research (1999) di Belanda menunjukkan bahwa industri kecil dan 
menengah(IKM) berjumlah 98,8 persen dari semua sektor perusahaan. Lebih lanjut ditemukan bahwa IKM dapat berkontribusi sebesar 31,6 persen pada PDBdan mempekerjakan 55 persen dari total tenaga kerja. Studi di Italia melaporkan, IKMmenyumbang 35 juta USD dalam ekspor dan menyerap 2,2 juta tenaga kerja nasional(Patrianila, 2003). Disisi lain, industri kecil dan menengah di Thailand dilaporkan sebagai sektor yang dapat menyerap lapangan kerja baru. Temuan yang sama juga dilaporkan pada industri kecil dan menengah di Vietnam dapat mempekerjakan 64 persen tenaga kerja pada sektor industri (Swierczek dan Ha, 2003).

(A)

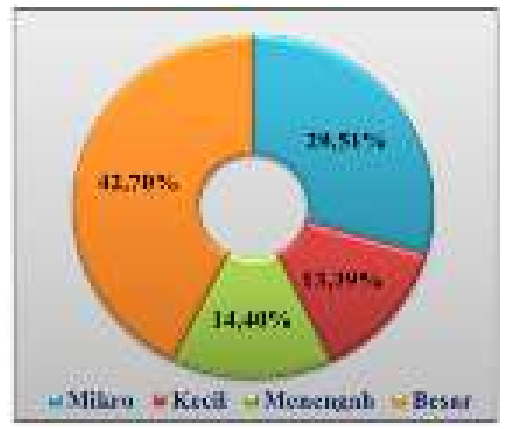

(B)

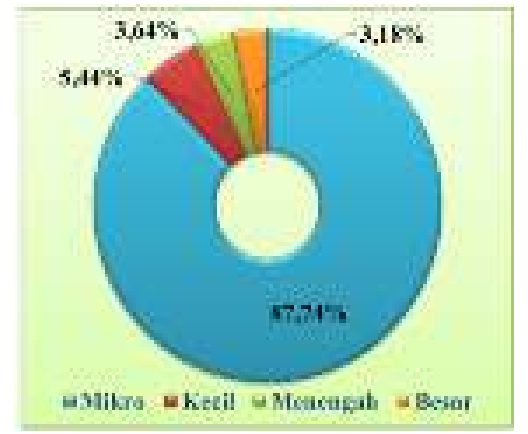

Sumber : Kementerian Koperasi dan UMKM serta Badan Pusat Statistik (BPS)

Gambar 1.Kontribusi Usaha Berdasarkan Skala Usaha terhadap Perekonomian Nasional Tahun 2017. (A) Kontribusi Terhadap PDB dan (B) Kontribusi Terhadap Penyerapan Tenaga Kerja

Industri mikro dan kecil mempunyai daya dorong yang signifikan pada perekonomian. Hal ini seperti yang digambarkan dalam Gambar 1. Keunggulan lain dari industri mikro dan kecil adalah kemampuannya bertahan dari guncangan krisis, meskipun banyak sektor usaha besar lainnya bangkrut. IMK tidak mendapat dampak krisis yang besar dibandingkan IMB karena minimnya interaksi IMK dengan mata uang asing (Tambunan, 2011).Penelitian yang dilakukan oleh Cameron (1999) dan Berry dkk (2001) juga melaporkan IMK telah berhasil melewati krisis ekonomi lebih baik dibandingkanIMB. Hal ini dikarenakan IMK kurang bergantung pada pasar formal dan dana pinjaman dengan bunga yang tinggi.

Laporan tahunan Bank Indonesia pada periode (2019) menyebutkan bahwa usaha mikro, kecil dan menengah (UMKM) berperan sebagai pengendali inflasi dan penurunan defisit transaksi berjalan. Pengendalian inflasi oleh Bank Indonesia terutama inflasi bahan pangan didukung oleh penguatan dalam UMKM melalui perbaikan sisi supply bahan pangan strategis yang berkontribusi besar terhadap inflasi. Peranan UMKM dalam penurunan defisit transaksi berjalan dapat dilakukan dengan peningkatan ekspor produk-produk UMKM.

Penelitian yang dilakukan oleh McKinsey (2019) menyebutkan bahwa Indonesia sedang memasuki era revolusi industri 4.0 dalam berbagai sektor. Diprediksikan sekitar enam belas persen dari aktivitas ekonomi saat ini akan beralih dari penggunaan tenaga kerja manusia menjadi sebagian besar akan dilakukan secara otomatisasi pada Tahun 2030 nanti. Berdasarkan kondisi tersebut paling tidak pada Tahun 2030 harus dapat menciptakan sedikitnya 27 juta lapangan pekerjaan baru di Indonesia. Kehadiran teknologi pada Revolusi Industri 4.0 akan menjadi tantangan dalam pasar tenaga kerja Indonesia. Para pemilik usaha akan semakin sulit menemukan pekerja dengan skill yang sesuai dengan kebutuhan. Penambahan jumlah IMK di Indonesia diharapkan mampu menciptakan lapangan kerja baru untuk menampung tenaga kerja yang tidak memiliki skill tinggi.

Teori ekonomi kriminalitas memprediksikan kejadian tindakpidana dan kejahatan berkorelasi positif dengan ketimpangan pendapatan (Ehrlich, 1973; Fanjzylber dkk, 2002).Di sisi 
lain, salah satu faktor yang dapat berpengaruh besar terhadap kemudahan dalam melakukan usaha adalah stabilitas politik dan tidak adanya tindak kejahatan atau kriminalitas (Kaufmann dkk, 1999). Kondisi tersebut juga harus ditunjang dengan faktor-faktor yang lain seperti infratruktur fisik, modal manusia serta tingkat pertumbuhan ekonomi suatu negara. Kaufmann dkk (1999) juga menemukan bahwa setiap kenaikan 1 persen pada stabilitas politik dan keberadaan kekerasan menyebabkan kenaikan pada indeks kemudahan dalam melakukan usaha sebesar 4,5 persen. Temuan ini memberi indikasi bahwa stabilitas politik dan keamanan, secara makro berpengaruh pada daya tarik dan peluang investor dalam memulai usaha.

Beberapa penelitian menunjukkan bahwa keberadaan aktivitas tindak kejahatan atau kriminalitas merupakan masalah utama yang dapat berdampak negatif terhadap perkembangan ekonomi khususnya untuk usaha atau industri yang memiliki skala lokal. Sebagai contoh penelitian yang dilakukan oleh Detotto dan Otranto (2010). Peneliti ini melaporkan bahwa adanya aktivitas tindak kejahatan atau kriminalitas berupa perampokan, pencurian, vandalisme dan pembakaran akan berdampak pada peningkatan biaya operasional untuk melakukan usaha tersebut. Kejadian tindak kejahatan tersebut dapat mengurangi keuntungan atau laba usaha, melalui kerugian materi dan immaterial yang ditimbulkan pada pengusaha. Selain itu, kerugian yang lain yang ditimbulkan dari adanya tindak kejahatan ini adalah pengalihan sumber daya yang mungkin disalurkan untuk investasi usaha,tetapi harus digunakan untuk pengeluaran untuk keamanan misalnya pemasangan atau pembelian alat untuk keamanan ataupun pembayaran jasa penjaga keamanan (Kimou, 2015).BenYishay dan Pearlman (2014) juga menemukan bahwa tingkat perampokan yang lebih tinggi dapat mengurangi kemampuan usaha atau industri berskala mikro untuk memperluas kegiatan dari usaha tersebut.Studi yang sama juga dikuatkan oleh penelitian Krkoska dan Robeck (2009).Kedua peneliti ini menemukan bahwa tindak kejahatan di Eropa dan Asia pada sebagian besar usaha menyebabkan berkurangnya kemampuan usaha, baik pengusaha maupun pihak investor untuk membuat investasi baru di region yang bersangkutan.

Kehadiran tindak kejahatan yang tinggi dapat menghambat investasi dan mengurangi daya saing perusahaan sehingga dapat menciptakan ketidakpastian dan inefisiensi (Kelly, 2000). Amin (2009) menemukan bahwa rata-rata kerugian akibatadanya kejadian tindak kejahatan sebesar 2,7 persen dari total penjualan tahunan usaha kecil dan menengah. Kerugian tersebut memiliki proporsi lebih besar daripada kerugian karena pengembangan penelitian dan pemadaman listrik. Penelitian lebih baru yang dilakukan oleh Islam (2014) menemukan bahwa akan terjadi peningkatan pertumbuhan PDB riil per kapita sebesar 1 persenjika terjadi penurunan kerugian sebesar 0,33 persen karena adanya tindak kejahatan bagi industri kecil dan menengah serta pengurangan sebesar 0,21 persen untuk industri berskala besar bagi perusahaan dalam pengembangan ekonomi.

Usaha mikro dan kecil dan menengah merupakan salah satu contoh sektor usaha yang rentan terhadap aktivitas tindak kejahatan. Hal ini dikarenakan karena sektor usaha tersebut kurang sumber daya keuangan yang memadai untuk berinvestasi dalam perlindungan, peralatan dan petugas keamanan. Sebagai contoh usaha jasa akomodasi lebih sensitif untuk terjadi aktivitas tindak kejahatan pada usaha perhotelan sedangkan restoran lebih rentan menjadi korban kejahatan yang dilakukan oleh pelanggan (Daunt dan Harris, 2011). Biasanya sektor akomodasi misalnya hotel dan restoran memiliki jam komersil yang lebih lama dan lebih banyak lagi kemungkinan terletak di daerah dengan tingkat kejahatan lokal yang lebih tinggi (Rosenthal dan Ross, 2010).

Penelitian yang dilakukan oleh Motta (2017) permasalahan utama yang dapat berdampak negatif terhadap perkembangan industri lokal di negara-negara berkembangadalah adanya tindak kejahatan seperti perampokan, pencurian, vandalisme dan pembakaran. Adanya tindak kejahatan tersebut akan meningkatkan biaya untuk melakukan usaha. Temuan keseluruhan penelitian 
tersebut menunjukkan bahwa ada hubungan negatif antara aktivitas kriminal dan kinerja perusahaan untuk usaha kecil dan menengah di Amerika Latin. Selain itu penelitian di China yang dilakukan oleh Broadhurst dan Bouhours (2013) menunjukkan semakin besar skala usaha yang dilakukan resiko untuk mengalami tindak kejahatan juga semakin besar terutama penipuan. Di United Kingdom pada Tahun 2017 usaha kecil yang bergerak dalam sektor perdagangan grosir dan eceran dan makanan merupakan sektor yang banyak banyak mengalami insiden kejahatan dengan tingkat prevalensi sebesar 44 persen jika dibandingkan sektor yang lain seperti transportasi, akomodasi, makanan dan lain-lain (Osborn, 2018).

Bates dan Robb (2008), di sisi lain menemukan bukti yang tidak meyakinkan tentang dampak negatif adanya tindak kejahatan pada kinerja usaha. Hal tersebut menunjukkan bahwa dalam penentuan lokasi usaha mempertimbangkan resiko adanya tindak kejahatan di lokasi tersebut.Pengangguran juga dikaitkan dengan aktivitas tingkat kejahatan yang lebih tinggi (Machin dan Meghir, 2004).Industri mikro, kecil dan menengah yang berkinerja lebih baik dapat meningkatkan lapangan kerja dan pada gilirannya mencegah kemunculan adanya kegiatan criminal di lokasi tersebut.

Tujuan penelitian ini adalah untuk mengetahui apakah faktor keamanan lingkungan yang diproksikan dengan adanya kejadian tindak kejahatan akan menghambat proses industrialisasi pada wilayah perdesaan di Indonesia pada Tahun 2018. Sampai dengan saat ini belum ada penelitian maupun bukti empiris yang meneliti efek dengan mengaitkan antara keberadaan aktivitas tindak kejahatan dengan perkembangan jumlah usaha mikro dan kecil pada level perdesaan di Indonesia. Fokus penelitian ini adalah penggunaan data level perdesaan di Indonesia sesuai dengan agenda pembangunan nasional yang berdasarkan Nawa Cita. Adapun Nawa Cita yang menjadi landasan tujuan tersebut adalah Nawa Cita ketiga yaitu "Membangun Indonesia dari Pinggiran dengan Memperkuat Daerah-daerah dan Desa dalam Kerangka Negara Kesatuan Republik Indonesia".

\section{METODE PENELITIAN}

\subsection{Data}

Data yang digunakan dalam penelitian ini menggunakan data sekunder yang bersumber dari Badan Pusat Statistik Republik Indonesia (BPS RI) Tahun 2018. Data sekunder yang digunakan tersebut merupakan seluruh data hasil pendataan potensi Desa/Kelurahan(PODES) di wilayah Republik Indonesia yangdikumpulkan menggunakan kuesioner pendataan PODES2018DesadanPODES2018-Nagari.

\subsection{Populasi dan Sampel}

Populasi dan sampel yang digunakan dalam penelitian ini merupakan keseluruhan wilayah administrasi pemerintahan terendah berdasarkan hasil pendataan Podes Tahun 2018 meliputi desa, kelurahan, UPT/SPT, dan nagari.Jumlah populasi dan sampel penelitian pada Tahun 2018 berjumlah 83.931 observasi.Unit observasi dalam penelitian ini merupakan desa, kelurahan dan UPT/SPT yang selanjutnya diproksikan menjadi wilayah administrasi pemerintahan terendah di Indonesia yang disebut dengan perdesaan. Banyaknya wilayah administrasi pemerintahan terendah menurut klasifikasi pemerintahan pada Tahun 2018 adalah sebagai berikut : desa berjumlah 74.517, kelurahan berjumlah 8.444, UPT/SPT berjumlah 51 dan Nagari berjumlah 919.

\subsection{Variabel}


Variabel dependen utama yang digunakan dalam penelitian adalah jumlah industri mikro dan kecil di perdesaan Indonesia pada Tahun 2018 menurut bahan baku utama. Untuk jenis data variabel dependen ini seluruhnya menggunakan skala data rasio. Industri mikro merupakan industri dengan jumlah pekerja paling banyak 4 orang, termasuk pengusaha didalamnya. Sedangkan industri kecil merupakan industri dengan jumlah pekerja paling sedikit berjumlah 5 orang dan paling banyak berjumlah 19 orang, termasuk pengusaha. Selain itu industri mikro dan kecil yang digunakan merupakan industri berdasarkan pengelolanya yaitu pihak yang menanggung resiko kerugian.

Industri mikro dan kecil yang digunakan sebagai variabel dependen utama seluruhnya bersumber dari pendataan Podes Tahun 2018. Variabel ini didapatkan dari kuisioner Podes2018Desa pada Blok XII Rincian 1201a - 1201h. Konsep dan definisi masing-masing variabel tersebut mengikuti konsep dan definisi yang diberikan oleh BPS RI. Adapun variabel dependen tersebut diuraikan sebagai berikut :

1) Industri barang dari kulit yang bahan baku utamanya berasal dari kulit. Misalnya industri pembuatan tas, sepatu, sandal dan lain sebagainya.

2) Industri barang dari kayu yang bahan baku utamanya berasal dari kayu dan sejenisnya. Contohnyaindustri pembuatan meubel atau furnitur, mainan dari kayu, lantai dari kayu dan lain sebagainya.

3) Industriyang bahan baku utamanya berasal dari logam mulia dan bahan-bahan dari logam. Contoh dari industri tersebut misalnya industri pembuatan anting-anting, gelang, cincin, dan pembuatan perhiasan lainnya dari emas atau perak serta bahanbahan dari logam.

4) Industri barang dari kain atau tenun yang bahan baku utamanya berasal dari kain atau benang dan sejenisnya. Misalnya kerajinan tenun, kain rajutan dan sulaman, konveksi, gorden, selimut, batik dan lain sebagainya.

5) Industriyang bahan baku utamanya berasal dari gerabah / keramik/porselen/batu dan sejenisnya. Misalnya alat-alat yang terbuat dari tanah liat yang kemudian dibakar (misalnya kendi, genteng, batu bata dan lain sebagainya).

6) Industri anyaman dengan bahan baku utamanya berasal dari bambu, rotan, pandan, rumput, dan sejenisnya. Contoh industri tersebut adalah tikar, tas, keranjang, kipas, dan sebagainya.

7) Industri makanan dan minuman termasuksemua industri yang menghasilkan produk makanan atau minuman dan sejenisnya serta termasuk pengolahan dan pengawetan makanan, daging, ikan, buah-buahan, sayuran, susu dan sebagainya.

8) Industri lainnya selain yang telah disebutkan sebelumnya.

Variabel independen merupakan kondisi keamanan lingkungan di perdesaan. Variabel ini diproksikan dengan keberadaan tindak kejahatan yang terjadi di perdesaan selama setahun terakhir. Tindak kejahatan yang dimaksudkan dalam variabel ini adalah segala tindakan yang disengaja atau tidak, telah terjadi atau baru percobaan, yang dapat merugikan orang lain dalam hal badan, jiwa, harta, benda, kehormatan, dan lainnya serta tindakan tersebut dapat diancam hukuman penjara atau kurungan. Variabel tersebut didapatkan dari kuisioner Podes2018-Desa pada Blok XIII Rincian 1301a dan Blok XIII Rincian 1303a01 Kolom 3 - 1303a10 Kolom 3. Keseluruhan variabel independen ini merupakan data dengan skala nominal dengan menggunakan kategori, bernilai 0 jika ada tindak kejahatan sedangkan bernilai 1 jika tidak ada tindak kejahatan yang terjadi di perdesaan selama setahun terakhir.

Konsep dan definisi variabel independen seluruhnya menggunakan konsepyang diberikan oleh BPS RI. Adapun variabel keamanan lingkungan yang digunakan dalam penelitian ini adalah sebagai berikut : 
1) Keberadaan kejadian perkelahian massal. Kejadian perkelahian massal yang terdapat dalam pendataan podes adalah perkelahian massal antar warga, pelajar, suku, atau lainnya di perdesaan yang disebabkan oleh saling ejek, salah paham, kenakalan remajaatau lainnya dengan yang melibatkan lebih dari 2 orang. Kejadian perkelahian massal dapat dikategorikan sebagai kejahatan dan dianggap sebagai suatu kondisi yang dapat mengganggu keamanan lingkungan.

2) Keberadaan tindak kejahatan pencurian. Pencurianadalah pengambilan barang tanpa hak dengan maksud memiliki tanpa disertai dengan kekerasan terhadap korban baik dengan pengrusakan maupun tidak.

3) Keberadaan tindak kejahatan pencurian dengan kekerasan atau perampokan. Perampokan adalah pencurian barang tanpa hak yang didahului, disertai, diikuti dengan kekerasan atau ancaman kekerasan terhadap korban dengan maksud akan menyiapkan atau memudahkan pencurian itu.

4) Keberadaan tindak kejahatan penipuan. Penipuanadalah perbuatan dengan maksud hendak menguntungkan diri sendiri atau orang lain secara melawan hak, memakai nama palsu atau keadaan palsu, akal tipu muslihat, perkataan bohong supaya memberikan uang atau barang. Sedangkan penggelapan adalah perbuatan dengan sengaja memiliki secara melawan hak atas suatu barang yang sekarang ini dikuasai pelaku, barang tersebut sebagian atau seluruhnya dimiliki oleh orang lain.

5) Keberadaan tindak kejahatan penganiayaan. Penganiyaanadalah perbuatan menyakiti orang lain secara fisik yang mengakibatkan korban menjadi sakit atau luka/cacat.

6) Keberadaan tindak kejahatan pembakaran. Pembakaranadalah perbuatan dengan sengaja membakar sesuatu, misalnya rumah, hutan, yang dapat mendatangkan bahaya bagi barang, jiwa, atau badan.

7) Keberadaan tindak kejahatan perkosaan/kejahatan terhadap kesusilaan. Perkosaanadalah pemaksaan terhadap korban untuk melakukan hubungan seksual dengan kekerasan atau ancaman. Pelecehan seksual dan sejenisnya dikelompokkan sebagai kejahatan terhadap kesusilaan.

8) Keberadaan tindak kejahatan penyalahgunaan narkoba. Penyalahgunaan narkobaadalah perbuatan menyalahgunakan atau mengonsumsi narkoba untuk kesenangan. Sedangkan peredaran narkoba adalah perbuatan menjual narkoba dengan imbalan berupa uang atau barang.

9) Keberadaan tindak kejahatan perjudian. Perjudianadalah perbuatan mempertaruhkan sejumlah uang atau harta yang bersifat untung-untungan, artinya bila tidak menang, uang atau barang taruhan hilang.

10) Keberadaan tindak kejahatan pembunuhan. Pembunuhanadalah perbuatan menghilangkan nyawa orang lain baik berencana maupun tidak. Dalam hal ini, pembunuhan dicatat di desa/kelurahan tempat jenazah korban pembunuhan tersebut ditemukan.

11) Keberadaan tindak kejahatan perdagangan orang. Perdagangan orangadalah upaya perekrutan, pengangkutan, pemindahan, penampungan, atau penerimaan seseorang dengan ancaman atau penggunaan kekerasan atau bentuk-bentuk paksaan lainnya, penculikan, pemalsuan, penipuan, penyalahgunaan kekuasaan atau posisi rentan ataupun memberi atau menerima bayaran atau manfaat sehingga memperoleh persetujuan dari orang yang memegang kendali atas orang lain, baik yang dilakukan di dalam negara maupun antar negara untuk tujuan eksploitasi atau mengakibatkan orang tereksploitasi. 
12) Keberadaan tindak kejahatan korupsi. Korupsi merupakan penyelewengan atau penyalahgunaan uang negara, perusahaanatau sebagainya yang dipergunakan untuk mencari keuntungan pribadi atau kelompok tertentu.

\subsection{Spesifikasi Model dan Estimasi}

Metode yang digunakan adalah regresi linear berganda dengan menggunakan software STATA.Sedangkan untuk estimasi parameter menggunakan metode OLS (Ordinary Least Square).Pengujian parameter regresi linear berganda ini menggunakan uji-t dan uji-F, pengukuran Godness of Fit atau ketepatan model dengan menggunakan $\mathrm{R}^{2}$ dan $\mathrm{R}^{2}$ adjusted.Gujarati dan Porter (2009 : 281) menyebutkan jika variabel dependen merupakan data berskala rasio sedangkan keseluruhan variabel independen berskala nominal, maka pemodelan datanya dapat digunakan metode regresi variabel dummy. Untuk menentukan apakah faktor kondisi keamanan lingkungan menghambat proses industrialisasi di perdesaan Indonesia digunakan model sebagai berikut :

Dalam bentuk fungsi yaitu :

\section{$\mathbf{Y}=\mathbf{f}$ (keberadaan tindak kejahatan)}

Sedangkan dalam bentuk persamaan umum modelsebagai berikut

$$
\begin{aligned}
& Y_{i}=\beta_{0}+\beta_{1} D_{1 i}+\beta_{2} D_{2 i}+\beta_{3} D_{3 i}+\beta_{4} D_{4 i}+\beta_{5} D_{5 i}+\beta_{6} D_{6 i}+\beta_{7} D_{7 i}+\beta_{8} D_{8 i}+\beta_{9} D_{9 i} \\
& + \\
& \beta_{10} D_{10 i}+\beta_{11} D_{11 i}+\beta_{12} D_{12 i}+u_{i}
\end{aligned}
$$

Dalam persamaan (1), Y adalah variabel dependen. Variabel dependen ini merupakan jumlah industri mikro dan kecil di perdesaan pada Tahun 2018 menurut bahan baku. Penelitian ini selanjutnya akan menggunakan 8 delapan variabel dependen atau variabel tak bebas yang terdiri dari $\mathrm{Y}_{1}$ : jumlah industri kulit, $\mathrm{Y}_{2}$ : industri kayu, $\mathrm{Y}_{3}$ : industri anyaman, $\mathrm{Y}_{4}$ : industri kain atau tenun, $\mathrm{Y}_{5}$ : industri gerabah atau keramik atau batu, $\mathrm{Y}_{6}$ : industri logam mulia atau bahan logam, $\mathrm{Y}_{7}$ : industri makanan dan minuman serta $\mathrm{Y}_{8}$ : industri lainnya.

Sedangkan variabel independen merupakan variabel dummy keamanan lingkungan yang diproksikan dengan keberadaan tindak kejahatan yang terjadi selama setahun terakhir di perdesaan per jenis kejahatan. Variabel independen ini terdiri dari 12 jenis variabel yang terdiri dari :

1) $D_{1}$ bernilai 1 jika ada kejadian perkelahian massaldan bernilai 0 jika tidak ada kejadian perkelahian massal di perdesaan

2) $\mathrm{D}_{2}$ bernilail jika ada kejadian tindak kejahatan pencurian di perdesaan dan bernilai 0 jika tidak ada kejadian tindak kejahatan pencurian di perdesaan

3) D D $_{3}$ ernilai 1 jika ada kejadian tindak kejahatan perampokan di perdesaan, sedangkan bernilai 0 jika tidak ada kejadian tindak kejahatan perampokan di perdesaan

4) D4bernilai 1 jika ada kejadian tindak kejahatan penipuan di perdesaan dan bernilai 0 jika tidak ada kejadian tindak kejahatan penipuan di perdesaan

5) Ds bernilai 1 jika ada kejadian tindak kejahatan penganiayaan di perdesaan dan bernilai 0 jika tidak ada kejadian tindak kejahatan penganiayaan di perdesaan

6) $\mathrm{D}_{6}$ bernilai 1 jika ada kejadian tindak kejahatan pembakaran di perdesaan dan bernilai 0 jika tidak ada kejadian tindak kejahatan pembakaran di perdesaan

7) $\quad \mathrm{D}_{7}$ bernilai 1 jika ada kejadian tindak kejahatan perkosaan di perdesaan dan bernilai 0 jika tidak ada kejadian tindak kejahatan perkosaan di perdesaan

8) $\mathrm{D}_{8}$ bernilai 1 jika ada kejadian tindak kejahatan narkoba di perdesaan dan bernilai 0 jika tidak ada kejadian tindak kejahatan narkoba di perdesaan 
9) D9bernilai 1 jika ada kejadian tindak kejahatan perjudian di perdesaan dan bernilai 0 jika tidak ada kejadian tindak kejahatan perjudian di perdesaan

10) $\mathrm{D}_{10}$ bernilai 1 jika ada kejadian tindak kejahatan pembunuhan di perdesaan dan bernilai 0 jika tidak ada kejadian tindak kejahatan pembunuhan di perdesaan

11) $D_{11}$ bernilai 1 jika ada kejadian tindak kejahatan perdagangan orang di perdesaan dan bernilai 0 jika tidak ada kejadian tindak kejahatan perdagangan orang di perdesaan

12) $\mathrm{D}_{12}$ bernilai 1 jika ada kejadian tindak kejahatan korupsi di perdesaan dan bernilai 0 jika tidak ada kejadian tindak kejahatan korupsi orang di perdesaan

Selain itu i merupakan jumlah perdesaan di Indonesia pada Tahun 2018, dimana $i=1,2$, $3, \ldots, 83.391$. Penelitian ini dilakukan dengan meregresikan masing-masing variabel dependen dengan 12 variabel dummy sehingga akan dihasilkan sejumlah 8 model regresi.

\section{TEMUAN DAN PEMBAHASAN}

Pada penelitian ini hanya memfokuskan pada jumlah industri mikro dan kecil per jenis industri menurut bahan baku di perdesaan pada 34 provinsi Indonesia. Hasil pendataan podes yang dilakukan oleh BPS RI pada Tahun 2018 menunjukkan industri makanan dan minuman merupakan salah jenis industri mikro dan kecil yang paling dominan di wilayah perdesaan Indonesia pada Tahun 2018. Industri makanan dan minuman berjumlah 629.569 unit usaha atau 34,80 persen dari keseluruhan unit usaha menurut bahan baku di seluruh perdesaan Indonesia. Setelah industri makanan dan minuman, industri anyaman dan kain / tenun menempati urutan kedua dan ketiga dengan masing-masing industri berjumlah 313.269 (17,32 persen) dan 272.770 (15,08 persen). Untuk industri terbanyak selanjutnya secara berturut-turut merupakan industri gerabah/keramik/batu, industri lainnya, industri kayu, industri logam mulia / bahan logam dan industri kulit dengan jumlah unit usaha dapat dilihat seperti pada Gambar 2 berikut.

Industri mikro dan kecil menurut bahan baku pada Tahun 2018 tersebar hampir merata di seluruh pelosok nusantara. Setiap provinsi di Indonesia pada level perdesaannya terdapat industri mikro dan kecil menurut bahan baku walaupun dengan jumlah unit usaha yang berbeda-beda pada setiap wilayah pada masing-masing provinsi. Pulau jawa masih mendominasi jumlah industri mikro dan kecil menurut bahan baku. Ada tiga provinsi di Pulau Jawa yang memiliki jumlah industri mikro dan kecil yang memiliki unit usaha lebih dari 100.000 unit usaha di wilayah perdesaannya, provinsi tersebut dari urutan tertinggi ke terendah berturut-turut yaitu Provinsi Jawa Tengah, Jawa Timur dan Jawa Barat.

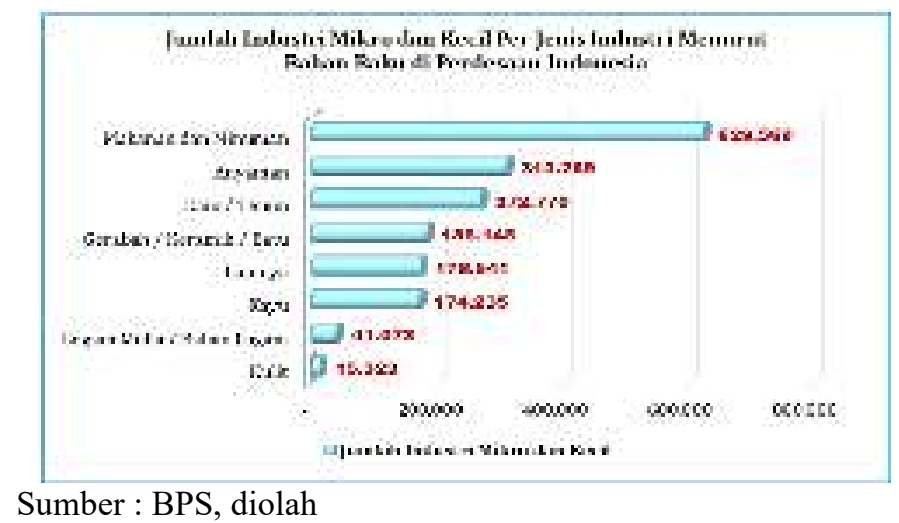

Gambar 2. Jumlah Industri Mikro dan Kecil per Jenis Industri Menurut Bahan Baku di Indonesia 
Untuk provinsi yang memiliki jumlah industri dalam rentang $75.000-100.000$ usaha berada di Provinsi Nusa Tenggara Timur. Selanjutnya provinsi yang memiliki industri dalamkategori sedang yaitu pada rentang 25.000 - 75.000 usaha di seluruh Indonesia berjumlah 11 provinsi. Selebihnya untuk wilayah provinsi yang perdesaannya hanya memiliki sedikit industri mikro dan kecil atau pada peta yang ditunjukkan pada Gambar 3 berjumlah 17 provinsi atau 50 persen provinsi di seluruh Indonesia. Walaupun Provinsi DKI Jakarta merupakan ibukota Indonesia namun ternyata data podes pada Tahun 2018 menunjukkan bahwa di wilayah perdesaannya hanya memiliki industri mikro dan kecil dengan jumlah tidak lebih dari sebelas ribu unit usaha. Hal ini menunjukkan industri mikro dan kecil pada wilayah ibukota kurang diminati sebagian besar penduduknya dan memilih sektor usaha lain misalkan industri menengah besar atau bahkan sektor jasa sebagai sektor unggulan yang menggerakkan perekonomian di wilayah tersebut.

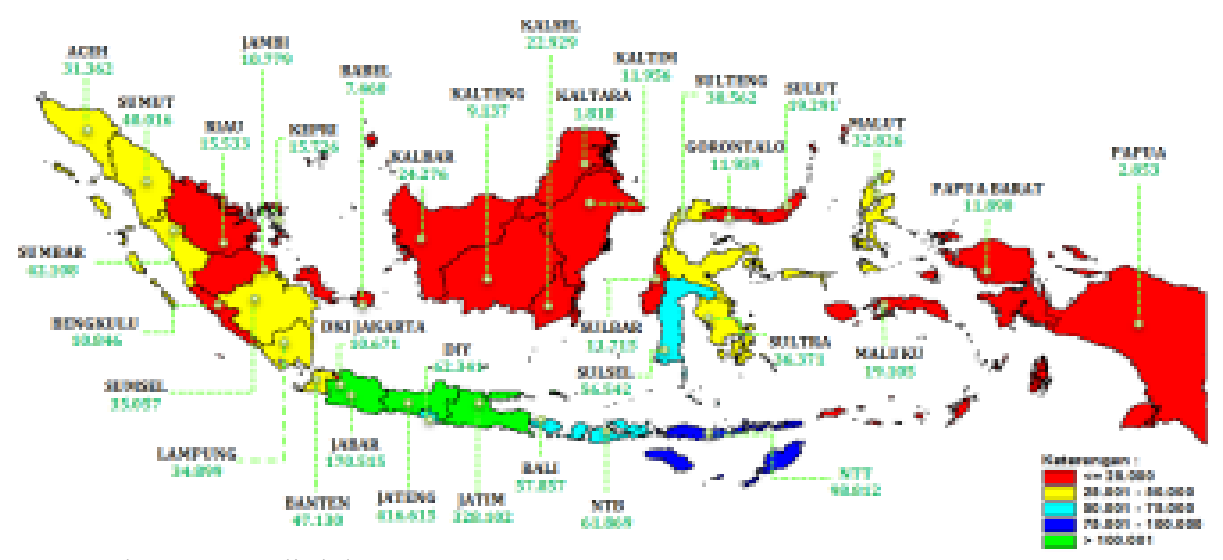

Sumber : BPS, diolah

Gambar 3. Peta Persebaran Jumlah Industri Mikro dan Kecil per Jenis Industri Menurut Bahan Baku di 34 Provinsi Indonesia

Penelitian yang dilakukan oleh Motta (2017) menyebutkan bahwa kendala yang dihadapi industri mikro dan kecil untuk dapat tumbuh dan berkembang salah satunya adalah tingkat keamanan di wilayah tersebut. Kondisi keamanan lingkungan dapat menjadi kendala utama yang dapat berdampak negatif terhadap industri-industri tersebut seperti misalnya adanya kejadian tindak kejahatan berupa perampokan, pencurian, vandalisme dan pembakaran yang dapat meningkatkan biaya untuk melakukan usaha.

Indonesia merupakan negara dengan populasi terbanyak keempat di dunia pada Tahun 2020 setelah Tiongkok, India dan Amerika Serikat yang juga tak lepas dari permasalahan keamanan terutama pada level pemerintahan terendah yaitu perdesaan. Data podes pada Tahun 2018 menunjukkan bahwa 45,01 persen atau sejumlah 37.778 wilayah perdesaan di seluruh Indonesia terdapat tindak kejahatan berupa pencurian. Aktivitas pencurian ini merupakan salah satu contoh kejadian yang paling sering atau dominan terjadi di wilayah perdesaan di Indonesia. Setelah itu aktivitas tindak kejahatan seperti perjudian dan narkoba menempati urutan kedua dan ketiga setelah pencurian yang mendominasi tindak kejatan yang dihadapi perdesaan di Indonesia. Kedua tindak kejahatan tersebut masing-masing sebesar 15,30 persen dan 14,99 persen pernah dialami oleh perdesaan di Indonesia. Untuk kejadian tindak kejahatan terbanyak yang pernah dialami perdesaan di Indonesia yaitu penipuan dengan jumlah 10,27 persen perdesaaan pernah mengalami jenis tindak kejatan tersebut. Sedangkan untuk jenis tindak kejahatan lainnya yang pernah terjadi di perdesaan Indonesia antara lain seperti penganiayaan, perkelahian massal, perkosaan, perampokan, pembunuhan,perampokan, pembakaran, korupsi dan perdangan orang. Jumlah perdesaan yang pernah mengalami jenis tindak kejahatan lainnya ini masing-masingnya tidak lebih dari 10 persen dari keseluruhan jumlah Perdesaan di Indonesia. Untuk jenis tindak 
kejahatan dan jumlah perdesaan yang pernah ada kejadian tersebut secara lebih lengkap dapat dilihat pada Gambar 4.

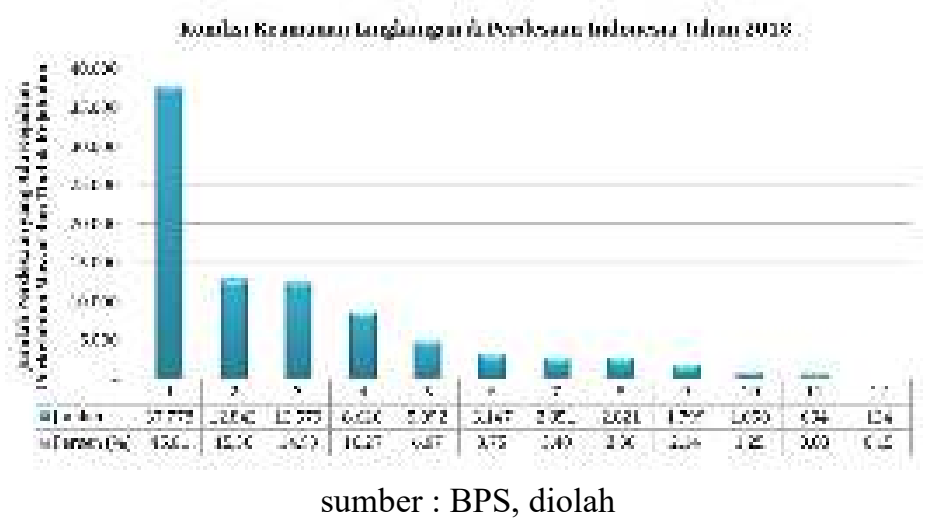

(1) Pencurian, (2) Perjudian, (3) Penyalahgunaan atau peredaran narkoba, (4) Penipuan, (5) Penganiayaan, (6) Perkelahian Massal, (7) Perkosaan, (8) Perampokan, (9) Pembunuhan, (10) Pembakaran, (11) Korupsi, dan (12) Perdagangan Orang

Gambar 4. Jumlah Keberadaan Tindak Kejahatan Per Jenis Tindak Kejahatan di Indonesia

Adanya aktivitas tindak kejahatan yang dihadapi oleh masing-masing perdesaan di Indonesia ini diharapkan tidak menjadi halangan untuk sektor industri mikro dan kecil menurut bahan baku untuk maju dan berkembang. Untuk mengetahui apakah dengan kondisi keamanan lingkungan yang demikian berpengaruh dalam menghambat proses industrialisasi di wilayah perdesaan Indonesia ini menjadi tujuan utama dalam penelitian ini.

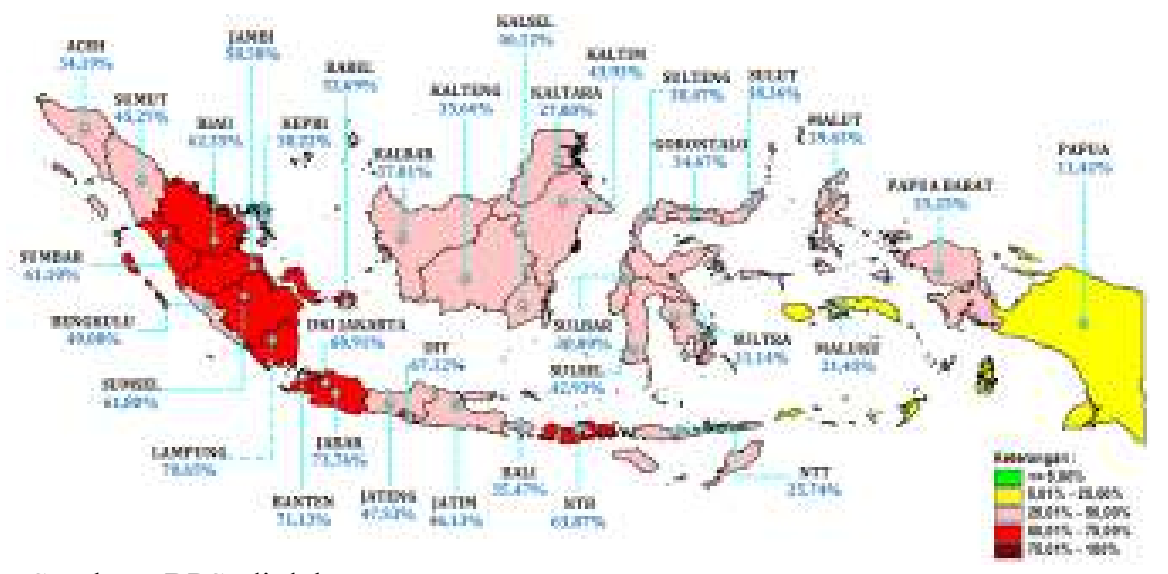

Sumber : BPS, diolah

Gambar 5. Peta Persebaran Persentase Jumlah Perdesaan yang Ada Kasus Tindak Kejahatan Pencurian di 34 Provinsi Indonesia

Gambar 5 menunjukkan bahwa 32 provinsi di Indonesia lebih dari 25 persen pada wilayah perdesaannya terdapat aktivitas tindak kejahatan berupa pencurian. Dimana dari jumlah tersebut 11 provinsi sudah berwarna merah yang menunjukkan bahwa lebih dari 50 persen wilayah perdesaannya pernah terdapat kasus tindak kejahatan berupa pencurian. Wilayah-wilayah yang sangat rawan tindak kejahatan pencurian sebagian besar berada pada wilayah dengan populasi penduduk yang besar seperti di Pulau Jawa dan Sumatera. Hanya ada dua provinsi di Indonesia yang wilayah perdesaannya cukup aman dari aktivitas pencurian ini yaitu Provinsi Maluku dan Papua. Kedua provinsi tersebut memiliki kurang dari 25 persen perdesaannya tercatat terdapat tindak kejahatan pencurian. 


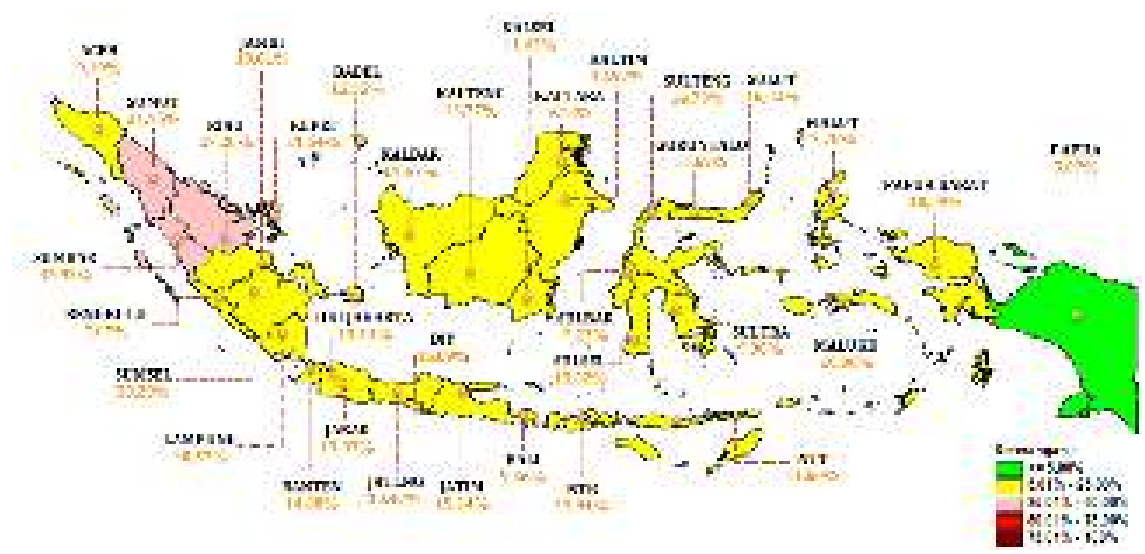

Sumber : BPS, diolah

Gambar 6. Peta Persebaran Persentase Jumlah Perdesaan yang Ada Kasus Tindak Kejahatan Perjudian di 34 Provinsi Indonesia

Jenis tindak kejahatan terbanyak kedua berikutnya setelah pencurian yaitu perjudian. Data pendataan podes pada Tahun 2018 menunjukkan bahwa hanya tiga provinsi di Indonesia dengan lebih dari 25 persen perdesaannya pernah melaporkan terdapat aktivitas tindak kejahatan berupa perjudian. Ketiga provinsi tersebut antara lain Provinsi Sumatera Barat, Sumatera Utara dan Riau yang semuanya berada di Pulau Sumatera. Selebihnya mayoritas 30 provinsi lain di Indonesia pada Tahun 2018 berada dalam kisaran 5 persen - 25 persen pada wilayah perdesaannya pernah terdapat kasus perjudian. Hanya ada satu saja provinsi di Indonesia yang wilayah perdesaannya kurang dari 5 persen perdesaannya pernah terdapat aktivitas tindak kejahatan perjudian yaitu Provinsi Papua. Hasil lengkap peta persebaran tindak kejahatan perjudian ini dapat dilihat pada Gambar 6.

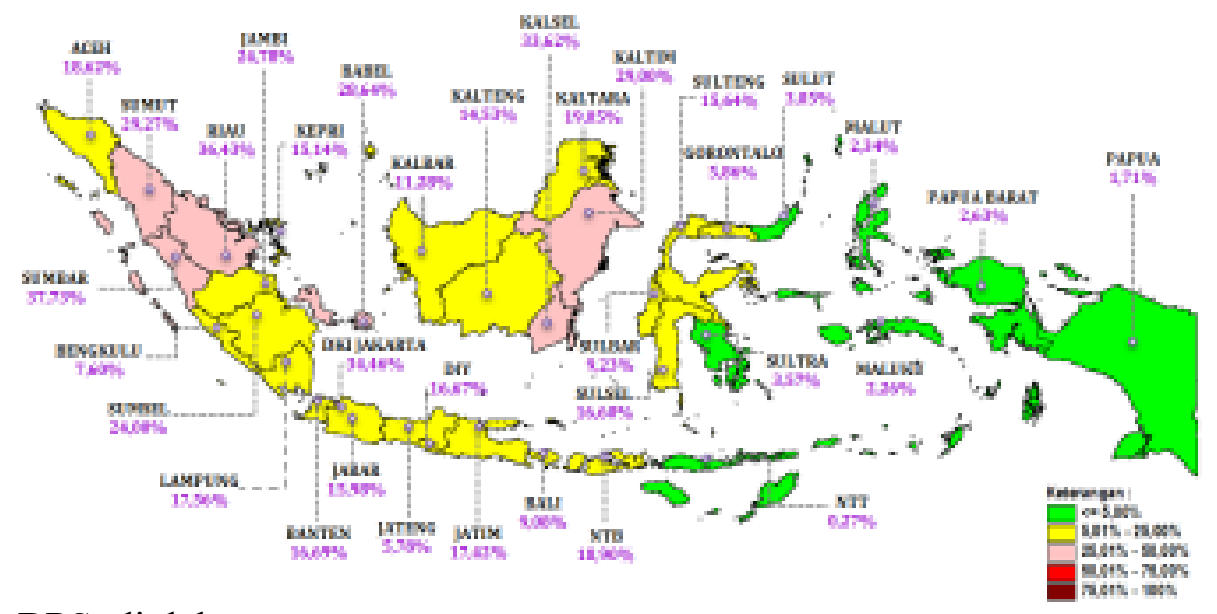

Sumber : BPS, diolah

Gambar 7. Peta Persebaran Persentase Jumlah Perdesaan yang Ada Kasus Tindak Kejahatan Penyalahgunaan atau Peredaran Narkoba di 34 Provinsi Indonesia

Jenis tindak kejahatan terbanyak ketiga selanjutnya yaitu penyalahgunaan atau peredaran narkoba. Berdasarkan data podes Tahun 2018 menunjukkan ada 7 provinsi terbanyak di Indonesia pada 25 persen - 50 persen wilayah perdesaanya yang pernah melaporkan adanya aktivitas penyalahgunaan atau peredaran narkoba selama setahun terakhir. Provinsi tersebut yaitu tersebut berturut-turut yaitu Provinsi Sumatera Barat (37,73 persen), Riau (36,43 persen), DKI Jakarta (34,46 persen), Kalimantan Selatan (33,62 persen), Kalimantan Timur (29,00 persen), 
Sumatera Utara (29,27 persen), Bangka Belitung (28,64 persen). Untuk wilayah provinsi yang berwarna hijau memiliki kasus tindak kejahatan yang relatif lebih rendah yaitu hanya 5 persen dari wilayah perdesaannya pernah melaporkan kejadian tersebut. Provinsi yang memiliki kasus relatif rendah untuk tindak kejahatan penyalahgunaan atau peredaran narkoba sebagian besar berada di wilayah timur Indonesia seperti Provinsi Maluku, Maluku Utara, Papua dan Papua Barat selebihnya berada pada wilayah Indonesia Tengah seperti Provinsi Sulawesi Utara, Sulawesi Teggara dan Nusa Tenggara Timur. Untuk provinsi dalam kategori sedang atau berwarna kuning ( 5 persen -25 persen) wilayah perdesaanya pernah melaporkan tindak kejahatan berupa penyalahguaan atau peredaran narkoba) secara lebih lengkap dapat dilihat pada Gambar 7.

Tabel 1. Hasil Regresi Variabel Dummy antara Jumlah Industri Mikro dan Kecil per Jenis Industri Menurut Bahan Baku dengan Keamanan Lingkungan per Jenis Kejadian di Perdesaan Indonesia 


\begin{tabular}{|c|c|c|c|c|c|c|c|c|c|}
\hline \multirow[b]{3}{*}{ No } & \multirow{3}{*}{$\begin{array}{l}\text { Variabel Independen : Jenis } \\
\text { Tindak Kejahatan }\end{array}$} & \multicolumn{8}{|c|}{ Variabel Dependen : Jumlah Industri Mikro dan Kecil per Jenis Industri di Perdesaan } \\
\hline & & $Y_{1}:$ & $Y_{2}:$ & 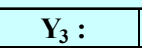 & $\mathrm{v}^{\prime}$ & 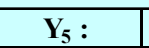 & $\mathbf{Y}_{6}:$ & $Y_{7}:$ & $\mathbf{Y}_{8}:$ \\
\hline & & Kulit & $\mathbf{u}$ & & & & an & $\begin{array}{c}\text { Makanan } \\
\text { dan } \\
\text { Minuman }\end{array}$ & Inya \\
\hline 1 & & $\begin{array}{r}0,0889 \\
{[0,0208]}\end{array}$ & $\begin{array}{r}1,4924 \\
{[0,0536]}\end{array}$ & $\begin{array}{r}0,2713 * \\
{[0.0320]}\end{array}$ & $\begin{array}{r}2,6730 * \\
{[0,1175]}\end{array}$ & $\begin{array}{r}1,5503 * \\
{[0,1034]}\end{array}$ & $\begin{array}{r}3,7080 * \\
{[0,1552]}\end{array}$ & $\begin{array}{r}5,6256 * \\
{[0,1492]}\end{array}$ & {$[0,1017]$} \\
\hline 2 & $\begin{aligned} D_{1} & : \text { Perkelahian Massal } \\
& (1=\text { Ada } ; 0=\text { Tidak Ada })\end{aligned}$ & $\begin{array}{r}-0,0430 \\
{[0,0812]}\end{array}$ & $\begin{array}{r}-0,0924 \\
{[0,2091]}\end{array}$ & $\begin{array}{l}-0,0679 \\
{[0,1249]}\end{array}$ & $\begin{array}{r}2,5343 * \\
{[0,4583]}\end{array}$ & $\begin{array}{c}-0,9221 * \\
{[0,4032]}\end{array}$ & $\begin{array}{l}-0,2514 \\
{[0,6054]}\end{array}$ & $\begin{array}{r}0,6922 \\
{[0.5820]}\end{array}$ & $\begin{array}{r}0,9145 * \\
{[0,3967]}\end{array}$ \\
\hline 3 & $\begin{aligned} \mathrm{D}_{2} & : \text { Pencurian } \\
& (1=\text { Ada } ; 0=\text { Tidak Ada })\end{aligned}$ & $\begin{array}{r}0,0898 * \\
{[0,0337]}\end{array}$ & $\begin{array}{r}0,8478 * \\
{[0,0869]}\end{array}$ & $\begin{array}{r}0,2418 * \\
{[0,0519]}\end{array}$ & $\begin{array}{r}0,5 \\
{[0,19}\end{array}$ & $\begin{array}{r}0,8319 * \\
{[0,1677]}\end{array}$ & $\begin{array}{r}0,8552 \\
{[0,2518]}\end{array}$ & $\begin{array}{r}2,5152 * \\
{[0.2420]}\end{array}$ & $\begin{array}{l}0,9005 * \\
{[0,1649]}\end{array}$ \\
\hline 4 & $\begin{aligned} \mathrm{D}_{3} & : \text { Perampokan } \\
& (1=\text { Ada } ; 0=\text { Tidak Ada })\end{aligned}$ & $\begin{array}{r}-0,0287 \\
{[0,0887]}\end{array}$ & $\begin{array}{r}0,5754 * \\
{[0,2286]}\end{array}$ & $\begin{array}{r}0,1178 \\
{[0,1366]}\end{array}$ & $\begin{array}{r}2,03 \\
{[0,50}\end{array}$ & $\begin{array}{r}0,2102 \\
{[0,4409]}\end{array}$ & $\begin{array}{l}-0,9671 \\
{[0,6619]}\end{array}$ & $\begin{array}{r}1,0571 \\
{[0,6363]}\end{array}$ & $\begin{array}{r}0,8716 * \\
{[0,4337]}\end{array}$ \\
\hline 5 & $\begin{aligned} \mathrm{D}_{4} & : \text { Penipuan } \\
& (1=\text { Ada } ; 0=\text { Tidak Ada })\end{aligned}$ & $\begin{array}{r}0,3041 * \\
{[0,0554]}\end{array}$ & $\begin{array}{r}1,2799 * \\
{[0,1428]}\end{array}$ & $\begin{array}{r}0,3663 * \\
{[0,0853]}\end{array}$ & $\begin{array}{r}1,0787 * \\
{[0.3130]}\end{array}$ & $\begin{array}{r}2,0269 * \\
{[0,2754]}\end{array}$ & $\begin{array}{r}0,5322 \\
{[0,4136]}\end{array}$ & $\begin{array}{r}4,3542 * \\
{[0,3975]}\end{array}$ & $\begin{array}{l}1,2355 * \\
{[0,2709]}\end{array}$ \\
\hline 6 & $\begin{aligned} \mathrm{D}_{5} & : \text { Penganiayaan } \\
& (1=\text { Ada } ; 0=\text { Tidak Ada })\end{aligned}$ & $\begin{array}{r}0,0339 \\
{[0,0687]}\end{array}$ & $\begin{array}{r}0,5677 * \\
{[0,1768]}\end{array}$ & $\begin{array}{r}0,5064 * \\
{[0,1057]}\end{array}$ & $\begin{array}{r}0,7073 \\
{[0,3876]}\end{array}$ & $\begin{array}{r}-0,0294 \\
{[0,3411]}\end{array}$ & $\begin{array}{r}0,5632 \\
{[0,5121]}\end{array}$ & $\begin{array}{r}2,0821 * \\
{[0,4922]}\end{array}$ & $\begin{array}{r}-0,1076 \\
{[0,3355]}\end{array}$ \\
\hline 7 & $\begin{aligned} \mathrm{D}_{6} & : \text { Pembakaran } \\
& (1=\text { Ada } ; 0=\text { Tidak Ada })\end{aligned}$ & $\begin{array}{l}-0,1320 \\
{[0.1390]}\end{array}$ & $\begin{array}{r}-0,2848 \\
{[0,3581]}\end{array}$ & $\begin{array}{r}0,1081 \\
{[0.2140]}\end{array}$ & $\begin{array}{r}0,1290 \\
{[0.7850]}\end{array}$ & $\begin{array}{c}-1,5439 * \\
{[0,6907]}\end{array}$ & $\begin{array}{r}0,4527 \\
{[1.0370]}\end{array}$ & $\begin{array}{c}-2,9089 * \\
{[0,9968]}\end{array}$ & $\begin{array}{r}0,1832 \\
{[0,6794]}\end{array}$ \\
\hline 8 & $\begin{aligned} \mathrm{D}_{7} & : \text { Perkosaan } \\
& (1=\text { Ada } ; 0=\text { Tidak Ada })\end{aligned}$ & $\begin{array}{r}0,1452 \\
{[0,0864]}\end{array}$ & $\begin{array}{c}-\mathbf{- 0 , 4 8 3 7} * \\
{[0,2227]}\end{array}$ & $\begin{array}{r}-0,0854 \\
{[0.1330]}\end{array}$ & $\begin{array}{r}-0,5067 \\
{[0,4881]}\end{array}$ & $\begin{array}{r}-0,4509 \\
{[0,4295]}\end{array}$ & $\begin{array}{r}-1,0523 \\
{[0,6448]}\end{array}$ & $\begin{array}{r}1,5865 * \\
{[0,6198]}\end{array}$ & $\begin{array}{l}-0,1853 \\
{[0,4225]}\end{array}$ \\
\hline 9 & $\begin{aligned} D_{8}: & \text { Penyalahgunaan Narkoba } \\
& (1=\text { Ada } ; 0=\text { Tidak Ada })\end{aligned}$ & $\begin{array}{r}0,1343 \\
{[0,0483]}\end{array}$ & $\begin{array}{r}0,2131 \\
{[0,1243]}\end{array}$ & $\begin{array}{r}0,4383 * \\
{[0,0743]}\end{array}$ & $\begin{array}{r}0,0284 \\
{[0,2725]}\end{array}$ & $\begin{array}{r}0,6450 * \\
{[0,2398]}\end{array}$ & $\begin{array}{c}-1,5308 * \\
{[0.3600]}\end{array}$ & $\begin{array}{r}0,4948 \\
{[0,3461]}\end{array}$ & $\begin{array}{r}-0,3347 \\
{[0,2359]}\end{array}$ \\
\hline 10 & $\begin{aligned} \mathrm{D}_{9} & : \text { Perjudian } \\
& (1=\text { Ada } ; 0=\text { Tidak Ada })\end{aligned}$ & $\begin{array}{r}-0,0072 \\
{[0,0481]}\end{array}$ & $\begin{array}{r}0,0611 \\
{[0,1238]}\end{array}$ & $\begin{array}{r}-0,1196 \\
{[0.0740]}\end{array}$ & $\begin{array}{r}0,2518 \\
{[0,2714]}\end{array}$ & $\begin{array}{r}0,4428 \\
{[0,2388]}\end{array}$ & $\begin{array}{c}-\mathbf{- 0 , 7 8 7 3} * \\
{[0,3585]}\end{array}$ & $\begin{array}{r}0,0787 \\
{[0,3446]}\end{array}$ & $\begin{array}{r}0,1116 \\
{[0,2349]}\end{array}$ \\
\hline 11 & $\begin{aligned} D_{10} & : \text { Pembunuhan } \\
& (1=\text { Ada } ; 0=\text { Tidak Ada })\end{aligned}$ & $\begin{array}{r}-0,0564 \\
{[0,1084]}\end{array}$ & $\begin{array}{r}-0,0920 \\
{[0,2792]}\end{array}$ & $\begin{array}{r}-0,2718 \\
{[0,1668]}\end{array}$ & $\begin{array}{r}-0,0714 \\
{[0,6121]}\end{array}$ & $\begin{array}{r}-0,3666 \\
{[0,5386]}\end{array}$ & $\begin{array}{r}-0,4410 \\
{[0,8086]}\end{array}$ & $\begin{array}{r}0,3161 \\
{[0,7773]}\end{array}$ & $\begin{array}{r}-0,9897 \\
{[0,5298]}\end{array}$ \\
\hline 12 & $\begin{aligned} D_{11}: & \text { Perdagangan orang } \\
& (1=\text { Ada } ; 0=\text { Tidak Ada })\end{aligned}$ & $\begin{array}{r}-0,3916 \\
{[0,4011]}\end{array}$ & $\begin{array}{r}-0,8314 \\
{[1,0331]}\end{array}$ & $\begin{array}{r}-0,0263 \\
{[0,6173]}\end{array}$ & $\begin{array}{r}1,0737 \\
{[2,2645]}\end{array}$ & $\begin{array}{r}4,0043 * \\
{[1,9926]}\end{array}$ & $\begin{array}{r}-0,8599 \\
{[2,9916]}\end{array}$ & $\begin{array}{r}3,1192 \\
{[2,8756]}\end{array}$ & $\begin{array}{r}2,3248 \\
{[1.9600]}\end{array}$ \\
\hline 13 & $\begin{aligned} D_{12}: & \text { Korupsi } \\
& (1=\text { Ada } ; 0=\text { Tidak Ada })\end{aligned}$ & $\begin{array}{r}0,2480 \\
{[0,1712]}\end{array}$ & $\begin{array}{r}0,2479 \\
{[0,4411]}\end{array}$ & $\begin{array}{r}-0,0620 \\
{[0,2635]}\end{array}$ & $\begin{array}{r}0,8716 \\
{[0,9667]}\end{array}$ & $\begin{array}{r}-1,6404 \\
{[0,8506]}\end{array}$ & $\begin{array}{r}-2,0135 \\
{[1,2771]}\end{array}$ & $\begin{array}{l}-0,8179 \\
{[1,2276]}\end{array}$ & $\begin{array}{r}-1,5574 \\
{[0,8367]}\end{array}$ \\
\hline 14 & Prob $>$ F & 0,0000 & 0,0000 & 0,0000 & $0,0000 *$ & $0,0000 *$ & $0,0000 *$ & $0,0000 *$ & 0,0000 \\
\hline & R-Squared & 0,0011 & 0,0045 & 0,0022 & 0,0015 & 0,0022 & 0,0006 & 0,0062 & 0,0011 \\
\hline & Adj R-Squared & 0,0010 & 0,0043 & 0,0021 & 0,0014 & 0,0020 & 0,0004 & 0,0060 & 0,0010 \\
\hline
\end{tabular}

Keterangan :*) Signifikan pada taraf $\alpha=5 \%$, [ ] Standard Error

Untuk melihat keterkaitan antara jumlah industri mikro dan kecil per jenis menurut bahan baku dengan keamanan lingkungan yang diproksikan dengan variabel keberadaan aktivitas tindak kejahatan digunakan regresi variabel dummy. Hasil regresi variabel dummy secara lengkap seperti yang ditunjukkan pada Tabel 1. Dengan menggunakan estimasi metode OLS didapatkan 8 model regresi variabel dummy. Pada taraf $\alpha$ sebesar 5 persen didapatkan hasil sebagai berikut:

1) Pada model pertama didapatkan tindak kejahatan pencurian, penipuan dan penyalahgunaan atau peredaran narkoba signifikan berpengaruh positif terhadap jumlah industri kulit diperdesaan Indonesia. Jumlah rata-rata keseluruhan industri kulit di perdesaan Indonesia pada Tahun 2018 sebesar 0,0889 unit ketika tidak ada tindak kejahatan sama sekali.

2) Pada model kedua, jumlah rata-rata keseluruhan industri kayu sebesar 1,4924 unit ketika tidak ada tindak kejahatan sama sekali. Selain itu tindak kejahatan pencurian, perampokan, penipuan, penganiayaan dan perkosaan berpengaruh terhadap jumlah industri kayu di perdesaan Indonesia. 
3) Model ketiga didapatkan jumlah rata-rata keseluruhan industri logam mulia / bahan logam sebesar 0,2713 unit ketika tidak ada tindak kejahatan sama sekali. Sedangkan tindak kejahatan yang berpengaruh terhadap jumlah industri logam mulia / bahan logam antara lain pencurian, penipuan, penganiayaan, dan penyalahgunaan / peredaran narkoba.

4) Pada model keempat, jika tidak ada tindak kejahatan maka jumlah rata-rata keseluruhan industri kain / tenun adalah sebesar 2,6730. Sedangkan perkelahian massal, tindak kejahatan pencurian, perampokan, dan penipuan berpengaruh terhadap jumlah industri kain / tenun tersebut.

5) Model kelima didapatkan jumlah rata-rata keseluruhan industri gerabah / keramik / batu adalah sebesar 1,5503 unit ketika tidak ada tindak kejahatan sama sekali. Serta didapatkan perkelahian massal dan tindak kejahatan pencurian, penipuan, pembakaran, penyalahgunaan / peradaran narkoba serta perdagangan orang merupakan variabel yang berpengaruh terhadap jumlah industri gerabah / keramik / batu.

6) Pada model keenam, tindak kejahatan pencurian, penyalahgunaan / peredaran narkoba dan perjudian merupakan variabel yang berpengaruh terhadap jumlah industri anyaman di perdesaan Indonesia. Jumlah rata-rata keseluruhan industri anyaman di perdesaan Indonesia pada Tahun 2018 sebesar 3,7080 unit ketika tidak ada tindak kejahatan sama sekali.

7) Jika tidak ada tindak kejahatan sama sekali maka jumlah rata-rata keseluruhan industri makanan dan minuman di perdesaan Indonesia adalah sebesar 5,6256 unit. Sedangkan tindak kejahatan yang berpengaruh terhadap industri makanan dan minuman tersebut adalah pencurian, penipuan, penganiayaan, pembakaran, dan perkosaan.

8) Untuk model terakhir, diperoleh jumlah rata-rata keseluruhan industri lainnya adalah sebesar 1,5819 unit saat tidak ada tindak kejahatan sama sekali. Selain itu perkelahian massal dan tindak kejahatan pencurian, perampokan, serta penipuan merupakan variabel yang berpengaruh terhadap jumlah industri lainnya.

Berdasarkan hasil pemodelan dengan menggunakan regresi variabel dummy yang telah dibahas pada bab sebelumnya menunjukkan ada beberapa kondisi keamanan lingkungan yang ditunjukkan oleh keberadaan aktivitas tindak kejahatan yang signifikan mempengaruhi jumlah industri mikro dan kecil di Indonesia. Kejadian perkelahian massal signifikan berpengaruh terhadap jumlah industri kain / tenun, gerabah / keramik / batu, dan industri lainnya. Adanya kejadian tindak kejahatan perampokan signifikan mempengaruhi jumlah industri kain / tenun dan industri anyaman. Keberadaan tindak kejadian tindak kejahatan penganiayaan mempengaruhi jumlah industri kayu, logam mulia / bahan logam dan industri makanan dan minuman. Adanya tindak kejahatan pembakaran mempengaruhi jumlah industri kulit, gerabah serta makanan dan minuman. Sedangkan untuk adanya tindak kejahatan perkosaan, penyalahgunaan narkoba, perjudian, pembunuhan, perdagangan orang serta korupsi secara tidak langsung dapat mempengaruhi beberapa jumlah industri seperti industri kulit, kayu, bahan logam, gerabah, anyaman dan industri lainnya. Sedangkan untuk adanya aktivitas tindak kejahatan yang pada umumnya terjadidan dijumpai seperti pencurian dan penipuandapat mempengaruhi sebagian besar jumlah industri mikro dan kecil di perdesaan Indonesia.

Ada hal yang menarik untuk dibahas berdasarkan hasil temuan penelitian ini adalah walaupun adanya tindak kejahatan pencurian dan penipuan mempengaruhi sebagian besar jumlah industri mikro dan kecil di perdesaan namun bukan berarti tindak kejahatan ini dapat menurunkan jumlah industri-industri tersebut.Adanya kejadian tindak kejahatan pencurian dan 
penipuan justru membuat rata-rata jumlah industri mikro dan kecil di perdesaan menjadi lebih tinggi dibandingkan ketika tidak ada kedua tindak kejahatan tersebut. Temuan hasil penelitian ini justru berbanding terbalik dengan hasil sebagian besar studi empiris pada bab sebelumnya yang mengatakan bahwa ketika ada tindak kejahatan di suatu lokasi atau tempat maka akan signifikan berpengaruh atau berdampak negatif terhadap industri lokal seperti industri mikro dan kecil di perdesaan ini. Hal ini tentunya dapat terjadi di perdesaan Indonesia yang memiliki keanekaragaman suku, etnis dan budaya membuat kejadian apapun akan memiliki dampak yang beraneka ragam pula di daerah tersebut. Selain itu data kondisi keamanan yang diproksikan dengan keberadaan tindak kejahatan yang diperoleh dari pendataan podes yang dilakukan oleh BPS RI Tahun 2018 merupakan data yang bersifat umum. Tindak kejahatan yang dicatat mungkin tidak terkait langsung dengan aktivitas kegiatan industri mikro dan kecil ini. Tindak kejahatan yang dicatat dalam data podes tidak hanya berupa tindak kejahatan yang terkait dengan hasil industri mikro dan kecil namun keseluruhan adanya tindak kejahatan yang pernah terjadi dan dilaporkan selama setahun terakhir dalam pendataan tersebut.

Faktor lain yang juga mungkin dapat menyebabkan hal tersebut mungkin dikarenakan oleh pelaku atau pemilik usaha-usaha mikro dan kecil di perdesaan ini tidak mengetahui tingkat kerawanan sosial seperti keberadaan aktivitas tindak-tindak kejahatan misalnya pencurian dan penipuan ini di lokasi tepat industri tersebut berada. Untuk itu mungkin perlu dilakukan kajian secara mendalam lagi terkait hal ini misalnya saja dilakukan pendataan yang berkelanjutan untuk mengetahui sejauh mana pelaku usaha mengerti dan memahami kondisi keamanan lingkungan di daerah tempat didirikannya industri atau usaha-usaha tersebut. Hasil penelitian ini sejalan dengan yang telah dilakukan oleh Bates dan Robb (2008). Penelitian tersebut juga menemukan bukti yang tidak meyakinkan tentang dampak negatif adanya tindak kejahatan pada kinerja usaha. Hal tersebut menunjukkan bahwa dalam penentuan lokasi usaha atau industri, pemilik usaha atau industri belum mempertimbangkan resiko adanya tindak kejahatan di lokasi tersebut.Hal ini juga menjadikan indikasi seperti penelitian yang dilakukan oleh Machin dan Meghir (2004) yang menunjukkan bahwa industri mikro, kecil atau bahkan menengah yang memiliki kinerja lebih baik dapat meningkatkan lapangan pekerjaan pada tingkat lokal dan pada gilirannya akan juga menimbulkan kemunculan adanya tindak kejahatan juga di lokasi tersebut.

Sebagian besar penelitian yang pernah dilakukan dengan mengaitkan antara adanya aktivitas tindak kejahatan dengan kinerja industri mikro, kecil atau menengah hanya membahas tentang dampak adanya kejahatan tersebut terhadap laba atau keuntungan saja. Penelitianpenelitian tersebut belum membahas dalam hal perkembangan jumlah industri-industri tersebut ketika ada atau tidak ada aktivitas tindak kejahatan yang terjadi di lokasi industri tersebut berada. Sedangkan pada penelitian yang dilakukan ini mengakaitkan antara keberadaan tindak kejahatan dengan perkembangan jumlah industri-industri mikro dan kecil pada level perdesaan di Indonesia. Selain itu untuk keberadaan adanya tindak kejahatan dalam penelitian ini menggunakan skala data nominal dengan kategori ada dan tidak untuk setiap jenis kejahatan. Sehingga hasil penelitian ini pun tidak bisa secara lebih mendalam mengetahui seberapa besar dampak yang timbulkan ketika ada aktivitas kejahatan per jenisnya terhadap jumlah industri mikro dan kecil di perdesaan Indonesia.

\section{KESIMPULAN DAN SARAN}

\subsection{Kesimpulan}

Hasil analisis dan pembahasan pada bab sebelumnya menunjukkan bahwa ada beberapa variabel kondisi keamanan lingkungan yang signifikan mempengaruhi atau dapat menghambatjumlah 
industri mikro dan kecil di perdesaan Indonesia. Namunada juga beberapa variabel kondisi keamanan lingkungan yang signifikan mempengaruhi jumlah industri mikro dan kecil di perdesaan Indonesia tetapi dengan keberadaanya justru membuat jumlah industri-industri tersebut menjadi lebih tinggi apabila dibandingkan pada saat tidak ada aktivitas tindak kejahatan tersebut.

Keberadaan tindak kejahatan seperti pencurian walaupun merupakan tindak kejahatan yang banyak dialami oleh sebagian besar perdesaan di Indonesia pada Tahun 2018, namun dengan adanya aktivitas kejahatan tersebut justru membuat jumlah industri mikro dan kecil menjadi meningkat atau lebih daripada tidak ada aktivitas pencurian. Hasil penelitian ini juga menunjukkan tindak kejahatan pencurian dan penipuan sebagian besar dapat mempengaruhi jumlah industri dan kecil pada umumnya di perdesaan Indonesia. Tetapi ketika ketika ada kejadian kedua tindak kejahatan tersebut justru membuat jumlah industri mikro dan kecil menjadi lebih tinggi dibandingkan pada saat tidak ada kejadian tindak kejahatan tesebut. Hal ini menunjukkan rata-rata keberadaan industri mikro dan kecil diperdesaan Indonesiabelum mempertimbangkan lokasi yang memiliki kecenderungan daerah dengan kerawanan sosial yang rendah seperti ditandai dengan minimnya atau rendahnya aktivitas tindak kejahatan di lokasi tersebut.

\subsection{Saran}

Penggunaan metode regresi variabel dummy dengan menggunakan estimasi Ordinary LeastSquare (OLS) sarat dengan pemenuhan asumsi klasik seperti pengujian normalitas, heterogenitas maupun multikolinearitas. Analisis data dengan menggunakan jumlah pengamatan yang sangat besar seperti penelitian ini, sulit untuk mendapatkan hasil nilai koefisien regresi yang efektif dan efisien jika menggunakan metode estimasi dengan menggunakan metode OLS. Untuk itu penelitian selanjutnya dapat digunakan model statistik ataupun metode estimasi parameter lainnya untuk lebih menghasilkan estimasi atau nilai dugaan koefisien model yang lebih efisien. Mungkin juga bisa ditambahkan variabel-variabel ekonomi lainnya seperti misalnya jumlah penduduk, mata pencaharian utama penduduk atau variabel lainnya yang berhubungan dengan peningkatan jumlah industri mikro dan kecil di perdesaan Indonesia. Selain itu untuk observasi berupa tahun tindak kejadian dapat dilakukan lebih dari satu titik pengamatan atau lebih dari satu tahun untuk lebih memperkaya dan memperdalam analisis serta pembahasan data nantinya.

\section{DAFTAR PUSTAKA}

Akhtar, M. R. (1997). Partnership financing of microenterprises.International Journal of Social Economics, 24(12), 1470-1480.

Amin, M. (2009).Crime, security and firms in Latin America.Enterprise Surveys.

Bank Indonesia.(2016). Pemetaan dan strategi peningkatan daya saing UMKM dalam menghadapi masyarakat ekonomi ASEAN (MEA) 2015 dan pasca MEA 2025.Jakarta: Departemen Pengembangan UMKM Bank Indonesia.

Bates, T., \& Robb, A. (2008). Crime's impact on the survival prospects of young urban small businesses. Economic Development Quarterly, 22(3), 228-238.

BenYishay, A., \& Pearlman, S. (2014). Crime and microenterprise growth: Evidence from Mexico. World Development, 56, 139-152. 
Berry, A., Rodriguez, E., \& Sandee, H. (2001).Small and medium enterprise dynamics in Indonesia.Bulletin of Indonesian Economic Studies, 37(3), 363-384.

Broadhurst, R., Bouhours, B., \& Bouhours, T. (2013).Business and the Risk of Crime in China.British Journal of Criminology, 53(2), 276-296.

BPS. (2019). Analisis hasil SE2016 lanjutan : potensi peningkatan kinerja usaha mikro dan kecil. Jakarta : Badan Pusat Statistik.

Cameron, L. (1999). Survey of recent developments.Bulletin of Indonesian Economic Studies, 35(1), 3-41.

Daunt, K. L., \& Harris, L. C. (2011). Customers acting badly: Evidence from the hospitality industry. Journal of Business Research, 64(10), 1034-1042.

Detotto, C., \& Otranto, E. (2010). Does crime affect economic growth?.Kyklos, 63(3), 330-345.

Ehrlich, I. (1973). Participation in illegitimate activities: A theoretical and empirical investigation. Journal of political Economy, 81(3), 521-565.

EIM Business \& Policy Research. (1999). Dutch SMEs in European Perspective: Zoetermeer.

Fanjzylber, P., Lederman, D., \& Loayza, N. (2002).Inequality and violent crime.Journal of Law and Economics, 45(1), 1-39.

Gujarati, D. N. \& Porter D.C. (2009). Basic econometrics fifith edition. New York : McGrawHill.

Islam, A. (2014). Economic growth and crime against small and medium sized enterprises in developing economies.Small Business Economics, 43(3), 677-695.

Kaufmann, D., Kraay, A., \& Zoido, P. (1999). Governance matters. World Bank policy research working paper, (2196).

Kimou, A. J. C. (2015). Crime, self-protection and business growth in cote d'Ivoire. Modern Economy, 6(10), 1101.

Kelly, M. (2000).Inequality and crime.Review of economics and Statistics, 82(4), 530-539.

Krkoska, L., \& Robeck, K. (2009). Crime, business conduct and investment decisions: Enterprise survey evidence from 34 countries in Europe and Asia. Review of Law \& Economics, 5(1), 493-516.

Machin, S., \& Meghir, C. (2004).Crime and economic incentives.Journal of Human resources, 39(4), 958-979.

Mazzarol, T., Volery, T., Doss, N., \& Thein, V. (1999). Factors influencing small business startups.International Journal of Entrepreneurial Behaviour and Research, 5(2), 48-63.

McKinsey Global Institute.(2019). Automation and the future of work in Indonesia. Chicago: McKinsey Global Institute. 
Motta, V. (2017). The impact of crime on the performance of small and medium-sized enterprises: Evidence from the service and hospitality sectors in Latin America. Tourism Economics, 23(5), 993-1010.

Osborn, S. (2018). Crime against businesses: findings from the 2017 Commercial Victimisation Survey. Statistical Bulletin, 7, 18.

Patrianila, V. N. (2003). Italia besarkan UKM dengan.Pengusaha (32), 70-71.

Rosenthal, S. S., \& Ross, A. (2010).Violent crime, entrepreneurship, and cities.Journal of Urban Economics, 67(1), 135-149.

Sato, Y. (2000). Linkage formation by small firms: The case of a rural cluster in Indonesia. Bulletin of Indonesian Economic Studies, 36(1), 137-166.

Swierczek, F. W., \& Ha, T. T. (2003). Entrepreneurial orientation, uncertainty avoidance and firm performance: an analysis of Thai and Vietnamese SMEs. International Journal of Entrepreneurship and Innovation, 4(1), 46-58.

Tambunan, T. T. (2011). Development of micro, small and medium enterprises and their constraints: A story from Indonesia. Gadjah Mada International Journal of Business, 13(1), 21-43. 